\title{
Value Assigned to Employees Who Preserve the Social and Organizational Environment
}

\author{
Crisanta-Alina Mazilescu ${ }^{1, *}$ and Bernard Gangloff ${ }^{2}$ \\ 1 Teacher Training Department, Politehnica University Timisoara, Timișoara 300006, Romania \\ 2 Laboratoire Parisien de Psychologie Sociale (LAPPS), Université Paris Ouest Nanterre La Défense, \\ Nanterre 92000, France; bernard.gangloff@univ-rouen.fr \\ * Correspondence: alina.mazilescu@gmail.com or alina.mazilescu@upt.ro; Tel.: +40-256-404-066 \\ Academic Editor: Giuseppe T. Cirella \\ Received: 2 December 2016; Accepted: 21 January 2017; Published: 25 January 2017
}

\begin{abstract}
In this study, we were interested in the behaviors of individuals who preserve the social and organizational environment by ensuring sustainability. More specifically, we are interested in allegiant behaviors. Numerous studies have highlighted the normative character of allegiance. Therefore, we questioned the value attributed to allegiance. We questioned 170 employees on social values that they attribute in terms of desirability and utility to a future colleague (subordinate or peer) starting from the responses that these future colleagues were supposed to have submitted to an allegiance questionnaire. It was observed that desirability and utility make reference to two independent dimensions, utility being often more important. It was also noted there is greater severity assigned to endo-group targets (future peers) than to exo-group targets (future subordinates). Finally, it was noted that there was not so much a valuation of allegiant targets, but rather a rejection of rebel targets, which raises the question of the bi-dimensionality of the valuation-devaluation process.
\end{abstract}

Keywords: allegiance norm; social desirability; social utility

\section{Introduction}

Sustainable development is a paradigm of modern society whose central objective "is to provide to everybody everywhere and at any time the opportunity to lead a dignified life in his or her respective society" [1] (p. 2).

Most studies have focused on economic and environmental sustainability, leaving its social aspects somewhat in the shadow [2]. In the literature, social aspects are usually referred to in terms of occupational health and safety, as well as ergonomics and work environment [3-5].

Social sustainability is a complex term which would require more attention in terms of its conceptual clarification. Chiu made a review of the interpretation given to the concept of social sustainability and identifies three directions [6]:

- A development-oriented interpretation, in which sustainable social development is based on respect for social acceptability as it contributes to social relations, rules, and values;

- An environment-oriented interpretation, when the social structure, social values, and norms are conducive to the sustainability of the environment;

- A people-oriented interpretation, when social sustainability is based on social cohesion, integrity, and social stability and prevents social polarization and exclusion.

Studies on sustainable behaviors in organizations are focused more on sustainability and sustainable leadership skills [7]. In the educational field, studies aim to identify competencies that support sustainable development with particular attention to the development of these skills [8-11]. 
Social psychology has tried to clarify, both in terms of understanding and developing a sustainable behavior, how people can be motivated to actively contribute to the transition to a sustainable society, but also of how that can be turned into a positive attitude towards the changes imposed by global climate changes.

Steg et al. [12] propose a general framework in what concerns the contribution of social and environmental psychology to understanding and promoting sustainable energy behavior by individuals and households: identification and measurement of behaviors to be changed, analysis of user behavior, designing and testing interventions to change behavior in order to reduce $\mathrm{CO}_{2}$ emissions, and the study of the factors that underlie the public acceptability of interventions and changes within the energy systems.

People who engage in sustainable behaviors are people oriented on a pro-environmental direction, acting according to their personal values and principles. The motivational factors, and especially values, are involved in the decision-making process with regard to identifying the efforts that a person is willing to commit to, but also in terms of costs and benefits of a sustainable behavior. Values are seen as a key factor in the development of sustainable behavior. They are motivational factors that can influence the beliefs and actions of those involved in the development of a sustainable society.

Four types of values have been identified as being involved in the development of a sustainable behavior related to sustainable energy use: hedonic values that orient people towards pleasure and comfort, egoistic values that focus people on safeguarding and personal resources, altruistic values that orient people towards the well-being of others and of society, and the biospheric values that focus people on the consequences for nature and the environment [13,14].

There are several psychological strategies that are used to increase people's motivation to engage in sustainable behavior. For example, information strategies are very successful, but strategies of social influence can also be used with good results. Among the latest, the most efficient are face-to-face strategies such as block-approach, behavior modeling, and commitments. Another recommended strategy to be used in order to encourage sustainable behavior is the social norms information strategy, when the others act sustainably [15].

Our research also addresses the field of social norms and values that are attributed to behaviors that preserve the social environment. We were interested in the behaviors of individuals who preserve the social and organizational environment by ensuring sustainability. More specifically, we are interested in allegiant behaviors.

At a corporate level, "an organization is sustainable provided it does not destroy the conditions prevailing at the time it was established" [7] (p. 213). The social valuation of the non-questioning of the social structure and its hierarchy of powers is perceived as a norm of allegiance [13]. The norm of allegiance occupies a particular place in relation to other norms. Indeed, the norm of allegiance corresponds to the non-questioning of a social functioning, and we have seen that the social norms underpin this functioning. Thus, allegiance can be understood as the tendency not to question other norms.

Several studies have demonstrated a professional valuation of employees who adopt allegiant conduct, that is to say a professional valuation of employees who preserve the social environment, especially the hierarchical one, from any questioning, thus ensuring its sustainability [16].

Studies in this field also show that the allegiant employees benefit from better professional success prognostics than their rebel counterparts, meaning non-allegiant [17-19], and that during the selection process, recruiters usually select the former instead of the latter (as part of a broader campaign to recruit workers from the automobile industry, after reviewing 1018 candidates) $[17,19,20]$. Other studies have even shown that the valuation of allegiant individuals may be doubled by a pathologization of rebels, the latter being considered to suffer from mental problems (according to Dagot \& Castra, as compared by 118 advisers for Local Missions [21] or to a pool of ANPE advisers, as compared by recruiters [22]). Moreover, if we make differentiations within the category of allegiance itself and if we examine (by experimentally manipulating) the reasons why individuals behave in an allegiant or a rebel manner, 
we notice that the individuals who adopt allegiant conduct due to their ideology (due to legality, considering that they must obey their superiors because of the latter's higher status) are preferred to mercenary allegiants, who act as such due to opportunism (based on personal interests [23]). We should also note that these results, collected in France, have been supplemented by studies conducted in other countries, such as Switzerland [24] or Argentina. For example, in Argentina it has been observed that managers prefer to work with allegiant subordinates than with rebel subordinates [25], and that the subordinates are aware of this preference [22]. Numerous studies highlight the existence of an allegiance norm [17-26].

To observe that a target (in our case, a person) is socially valued means that this target has some value in terms of desirability and utility [27-30]. Social value is considered to entail two dimensions: a desirable dimension, which refers to the emotional or motivational register, and a useful one, rooted in social functioning and more particularly in the economical field (Peeters speaks about "self-profitability" [31], while Beauvois speaks about "social utility" [32]. The difference that exists at a conceptual level between self-profitability and social utility was not found by Cambon, Djouary, and Beauvois [33] in their empirical studies. Their studies found that what is profitable for oneself is also useful for society. Le Barbenchon, Cambon, and Lavigne found contradictory results in what regards the correlations between desirability and utility: positive correlations, negative correlations, or total lack of correlations [34].

Several scales were used to measure this value. Le Barbenchon, Cambon, and Lavigne have used two scales for desirability which refer to the ability to have friends and to be loved and two scales for utility that relate to salary and the success in professional life [30]. Mazilescu, Abdellaoui, and Gangloff have used another procedure which refers to the value attributed to the fact that an individual has some personality traits related to the 'Big Five' dimensions [35].

These authors considered, on the one hand, that to measure desirability only by the ability to be loved and by the number of friends one has was very restrictive (a similar point can be made for measuring utility), and on the other hand that neither of these measures was methodologically satisfactory, considering, for example, that the opposite of "to have everything to be loved" was not "to have nothing to be loved", but rather "to have everything to be hated", or that the opposite of "to have everything to succeed in one's professional life" was not "to have nothing to succeed in one's professional life" but "to have everything to fail in one's professional life". Mazilescu, Abdellaoui, and Gangloff used two scales for desirability and two scales for utility. The same scales were also used by Gangloff [36], who investigated the value attributed to an information regarding a level of Allegiance (be it ideological or mercenary) of a future work colleague. This study is interested in the social value of information referring to a level of allegiance and not the social value of allegiance. It also seemed pertinent to us to examine the value attributed to allegiance in itself (by examining ideological allegiance and mercenary allegiance in a differentiated manner), the question therefore being: is having to work with an allegiant (vs. a rebel) colleague considered agreeable (or useful); or, more simply put, is an allegiant (vs. a rebel) colleague agreeable or useful? Considering the results of Gangloff [36], we assumed that the value attributed to allegiance may vary according to whether the target was a subordinate or a peer.

These elements have also led, in terms of the main hypotheses, to estimating that allegiance would be more anchored in utility than in desirability, and that rebellion would be more stigmatized when it concerned a subordinate, than when it characterized a peer.

\section{Materials and Methods}

Participants were recruited randomly, on a voluntary basis, from small and medium-sized enterprises in Rouen (France). The criteria were: to be employed in the services sector, to be male (controlled variable), and to have (for some) or not have (for others) subordinates to manage. 170 male managers (of which 89 with subordinates and 81 without any hierarchical responsibility), contacted at their place of work, responded, voluntarily, to two items (one of desirability and the second of utility), 
concerning their valuation of fictitious responses which a future work colleague was supposed to have provided, during a skills assessment, to a questionnaire on allegiance.

The participants were given the following task: "In the following questionnaire, you are asked to imagine that you will soon have a new work colleague (vs. a new subordinate). You only have a little information on that person: you do not know whether they are male or female, or their age, etc. In the following pages, you can read some of the answers that person has provided to a questionnaire during a skills assessment. For example, you find out that the person in question has said: 'I am a dynamic, ambitious person, who loves challenges.' You will then be required to indicate on the one hand if such a person seems agreeable, indifferent, or disagreeable to you, and then explain why; and on the other hand if you believe that such a person would be useful, not useful or, on the contrary, that they would be interfering with your work, and then explain why."

Then followed the fictitious answers given by the future work colleague and the questions on desirability and utility.

The questionnaire to which the future colleague was supposed to have answered is the questionnaire on allegiance/rebellion of Duchon and Gangloff [20]. It includes 12 items (three items of ideological allegiance, three items of ideological rebellion, three items of mercenary allegiance, and three items of mercenary rebellion): Appendix A. Four future colleague profiles have been created: a future colleague who complied for ideological reasons, a future colleague who complied for mercenary reasons, a future rebellious colleague who complied for ideological reasons, and a future rebellious colleague who complied for mercenary reasons.

Among the 89 managers with subordinates, 50 were confronted with the profile of an ideological allegiant future subordinate and with the profile of a mercenary allegiant future subordinate, and 39 with the profile of an ideological rebellious future subordinate and with the profile of a mercenary rebellious future subordinate (the order effect was neutralized). Among the 81 managers without subordinates, 40 were confronted with the profile of an ideological allegiant future peer and with the profile of a mercenary allegiant future peer, and 41 with the profile of an ideological rebellious future peer and with the profile of a mercenary rebellious future peer (the order effect was also neutralized).

After taking knowledge of those profiles, the participants had to express their appreciation of their future colleague, in terms of desirability on the one hand, and in terms of utility on the other hand, answering to the two following questions (coming from Mazilescu et al. [35]: for the justification of these questions):

(1) Do you believe that, while working with that person, you would consider them: someone agreeable; someone who leaves you indifferent; someone disagreeable?

(2) Do you believe that while working with that person, they would be: useful, useless, or interfering?

\section{Results}

Our results have been analyzed from the perspective of four variables studied: the allegiance-non-allegiance dimension, social value (social desirability-social utility), positive-neutral or negative judgments, and peer-subordinate status.

The analysis of the results is structured as follows:

- Identifying the differences between the desirability and the utility of allegiant—non-allegiant (rebel) persons, by also taking into consideration the ideological or mercenary dimension;

- Identifying the differences between positive, neutral, or negative judgments, both in appreciating the desirability of the allegiant behavior, as well as in appreciating its social utility. In this situation, we have also taken into account whether the persons evaluated are work colleagues or subordinates;

- Identifying the differences regarding the evaluation of the allegiant-non-allegiant behavior according to the status of the persons in question (peers or subordinates); 
- Identifying the differences between positive, neutral, or negative judgments regarding the useful or desirable value of allegiant-non-allegiant persons (also taking into consideration the ideological or mercenary dimension).

The collected responses were analyzed by ANOVA, and for calculating the effect size we use Cohen's $d$ in which, conventionally, we considered the three following levels: negligible effect ( 0 to 0.35 ), intermediate effect ( 0.35 to 0.65 ), and notable effect (up to 0.65$)$. Only the statistics that led to significant results are presented below. The gross results are given in Appendix B.

\subsection{Effects of the Type of Judgment (Desirability/Utility)}

We notice from the very beginning an effect of the type of judgment: desirability and utility do not lead to identical judgments. In terms of positive evaluations, the data is systematically higher for utility than for desirability, while for neutral evaluations, the reverse is valid (Table 1).

Table 1. Means and effects of the type of judgments (desirability and utility), globally.

\begin{tabular}{lcccccccc}
\hline \multirow{2}{*}{$\begin{array}{c}\text { Subjects } \\
\text { Targeted }\end{array}$} & \multicolumn{4}{c}{ Level of Desirability } & \multicolumn{3}{c}{ Level of Utility } & \multirow{2}{*}{ F (Snedecor) and $\boldsymbol{d}$ (Cohen) } \\
\cline { 2 - 7 } & Positive & Neutral & Negative & Positive & Neutral & Negative & \\
\hline sbd. global & 0.26 & - & - & 0.63 & - & - & $\mathrm{F}(1,176)=12.84 ; p=0.0004 ; d=0.54$ \\
peer global & 0.22 & - & - & 0.59 & - & - & $\mathrm{F}(1,160)=11.76 ; p=0.0007 ; d=0.54$ \\
alleg. global & 0.26 & - & - & 0.67 & - & - & $\mathrm{F}(1,178)=15.90 ; p=0.0001 ; d=0.59$ \\
rebel global & 0.23 & - & - & 0.55 & - & - & $\mathrm{F}(1,158)=9.05 ; p=0.003 ; d=0.47$ \\
\hline $\begin{array}{l}\text { peer global } \\
\text { alleg. global }\end{array}$ & - & 0.74 & - & - & 0.48 & - & $\mathrm{F}(1,160)=5.33 ; p=0.022 ; d=0.36$ \\
\hline
\end{tabular}

alleg.- -allegiant; sbd.--subordinate; Means were calculated by dividing the number of occurrences by the number of participants (in this case: 89 for subordinates, 81 for peers, 90 for allegiants, and 80 for rebels).

Finer analyses differentiate the ideological targets from the mercenary targets, reinforcing the global results. In terms of ideologists as well as of mercenaries, the positive evaluations are more numerous for utility than for desirability, and the results are reversed for neutral evaluations (for ideologists) and negative evaluations (for mercenaries) (Table 2).

Table 2. Means and effects of the type of judgments (desirability and utility), with differentiation between ideological and mercenary targets.

\begin{tabular}{|c|c|c|c|c|c|c|c|}
\hline \multirow{2}{*}{$\begin{array}{l}\text { Subjects } \\
\text { Targeted }\end{array}$} & \multicolumn{3}{|c|}{ Level of Desirability } & \multicolumn{3}{|c|}{ Level of Utility } & \multirow{2}{*}{ F (Snedecor) and $d$ (Cohen) } \\
\hline & Positive & Neutral & Negative & Positive & Neutral & Negative & \\
\hline id. sbd. & 0.20 & - & - & 0.43 & - & - & $\mathrm{F}(1,176)=10.95 ; p=0.001 ; d=0.49$ \\
\hline id. peer & 0.15 & - & - & 0.41 & - & - & $\mathrm{F}(1,160)=14.62 ; p=0.0002 ; d=0.60$ \\
\hline id. alleg. & 0.19 & - & - & 0.47 & - & - & $\mathrm{F}(1,178)=17.08 ; p=0.0001 ; d=0.62$ \\
\hline id. rebel & 0.16 & - & - & 0.36 & - & - & $\mathrm{F}(1,158)=8.60 ; p=0.0038 ; d=0.46$ \\
\hline merc. sbd. & 0.06 & - & - & 0.20 & - & - & $\mathrm{F}(1,176)=8.76 ; p=0.0035 ; d=0.45$ \\
\hline merc. peer & 0.07 & - & - & 0.19 & - & - & $\mathrm{F}(1,160)=4.50 ; p=0.0354 ; d=0.33$ \\
\hline merc. alleg. & 0.07 & - & - & 0.20 & - & - & $\mathrm{F}(1,178)=7.12 ; p=0.008 ; d=0.39$ \\
\hline merc. rebel & 0.06 & - & - & 0.19 & - & - & $\mathrm{F}(1,158)=5.85 ; p=0.0166 ; d=0.38$ \\
\hline id. subord. & - & 0.51 & - & - & 0.33 & - & $\mathrm{F}(1,176)=6.05 ; p=0.0148 ; d=0.37$ \\
\hline id. peer & - & 0.43 & - & - & 0.21 & - & $\mathrm{F}(1,160)=9.61 ; p=0.0022 ; d=0.49$ \\
\hline id. alleg. & - & 0.58 & - & - & 0.32 & - & $\mathrm{F}(1,178)=12.57 ; p=0.0005 ; d=0.53$ \\
\hline merc. sbd. & - & - & 0.61 & - & - & 0.45 & $\mathrm{~F}(1,176)=4.48 ; p=0.0350 ; d=0.32$ \\
\hline merc. rebel & - & - & 0.73 & - & - & 0.58 & $\mathrm{~F}(1,158)=4.005 ; p=0.047 ; d=0.32$ \\
\hline
\end{tabular}

\subsection{Effects of the Level of Judgement (Positive, Neutral, Negative)}

We also notice a differentiation according to the level of judgment: we observe (Table 3) that negative evaluations are more numerous than neutral evaluations (except for desirability of allegiants), 
which in turn are more numerous than the positive evaluations; and negative evaluations are more numerous than positive ones.

Table 3. Means and effects of the level of judgment (positive, neutral, negative), globally.

\begin{tabular}{|c|c|c|c|c|c|c|c|}
\hline \multirow{2}{*}{$\begin{array}{l}\text { Subjects } \\
\text { Targeted }\end{array}$} & \multicolumn{3}{|c|}{ Level of Desirability } & \multicolumn{3}{|c|}{ Level of Utility } & \multirow{2}{*}{$\mathrm{F}$ (Snedecor) and $d$ (Cohen) } \\
\hline & Positive & Neutral & Negative & Positive & Neutral & Negative & \\
\hline peers global & - & 0.74 & 1.04 & - & - & - & $\mathrm{F}(1,160)=4.80 ; p=0.030 ; d=0.34$ \\
\hline rebels global & - & 0.45 & 1.21 & - & - & - & $\mathrm{F}(1,158)=19.55 ; p \approx 0.000 ; d=0.69$ \\
\hline alleg. global & - & 1.00 & 0.74 & - & - & - & $\mathrm{F}(1,178)=4.62 ; p=0.032 ; d=0.32$ \\
\hline peers global & - & - & - & - & 0.48 & 0.93 & $\mathrm{~F}(1,160)=13.36 ; p \approx 0.000 ; d=0.57$ \\
\hline rebels global & - & - & - & - & 0.45 & 1.00 & $\mathrm{~F}(1,158)=19.54 ; p \approx 0.000 ; d=0.69$ \\
\hline sbd. global & 0.26 & 0.84 & - & - & - & - & $\mathrm{F}(1,176)=36.70 ; p \approx 0.000 ; d=0.90$ \\
\hline peers global & 0.22 & 0.74 & - & - & - & - & $\mathrm{F}(1,160)=21.89 ; p \approx 0.000 ; d=0.77$ \\
\hline alleg. global & 0.26 & 1.00 & - & - & - & - & $\mathrm{F}(1,178)=53.40 ; p=0.000 ; d=1.09$ \\
\hline rebels global & 0.23 & 0.56 & - & - & - & - & $\mathrm{F}(1,158)=11.68 ; p=0.001 ; d=0.54$ \\
\hline sbd. global & 0.26 & - & 0.90 & - & - & - & $\mathrm{F}(1,176)=36.86 ; p \approx 0.000 ; d=0.91$ \\
\hline peers global & 0.22 & - & 1.04 & - & - & - & $\mathrm{F}(1,160)=47.34 ; p \approx 0.000 ; d=1.08$ \\
\hline alleg. global & 0.26 & - & 0.74 & - & - & - & $\mathrm{F}(1,178)=21.69 ; p \approx 0.000 ; d=0.69$ \\
\hline rebels global & 0.23 & - & 1.21 & - & - & - & $\mathrm{F}(1,158)=75.77 ; p \approx 0.000 ; d=1.38$ \\
\hline peers global & - & - & - & 0.59 & - & 0.93 & $\mathrm{~F}(1,160)=6.148 ; p=0.014 ; d=0.38$ \\
\hline rebels global & - & - & - & 0.55 & - & 1.00 & $\mathrm{~F}(1,158)=10.86 ; p \approx 0.000 ; d=0.52$ \\
\hline
\end{tabular}

alleg.-allegiant; sbd.--subordinate.

In what concerns the effects of the level of judgment (positive, neutral, negative) on ideologists, we notice (Table 4) that in half of the cases, the negative evaluations are more numerous than the neutral evaluations, which in turn are more numerous than the positive evaluations. Nevertheless, we also notice six reversed cases: therefore the positive evaluations may be more intense than the neutral ones (in what concerns the utility of peers, subordinates, allegiants, and rebels) and the negative ones (in what concerns the utility of allegiants), and the neutral may prove more intense than the negative ones (in what concerns the desirability of subordinates).

Table 4. Means and effects of the level of judgment (positive, neutral, negative) on ideologists.

\begin{tabular}{lccccccc}
\hline \multicolumn{1}{r}{$\begin{array}{c}\text { Subjects } \\
\text { Targeted }\end{array}$} & \multicolumn{2}{c}{ Level of Desirability } & \multicolumn{3}{c}{ Level of Utility } & F (Snedecor) and $d$ (Cohen) \\
\cline { 2 - 6 } & Positive & Neutral & Negative & Positive & Neutral & Negative & \\
\hline id. peers & - & - & - & - & 0.21 & 0.38 & $\mathrm{~F}(1,160)=5.94 ; p=0.016 ; d=0.38$ \\
id. rebels & - & - & - & - & 0.21 & 0.43 & $\mathrm{~F}(1,158)=8.66 ; p=0.0037 ; d=0.46$ \\
id. sbd. & 0.20 & 0.51 & - & - & - & - & $\mathrm{F}(1,176)=19.69 ; p \approx 0.000 ; d=0.66$ \\
id. peers & 0.15 & 0.43 & - & - & - & - & $\mathrm{F}(1,160)=17.36 ; p \approx 0.000 ; d=0.65$ \\
id. alleg. & 0.19 & 0.58 & - & - & - & - & $\mathrm{F}(1,178)=33.89 ; p \approx 0.000 ; d=0.87$ \\
id. rebels & 0.16 & 0.35 & - & - & - & - & $\mathrm{F}(1,158)=7.64 ; p=0.006 ; d=0.44$ \\
id. alleg. & 0.23 & 0.58 & - & - & - & - & $\mathrm{F}(1,178)=24.97 ; p \approx 0.000 ; d=0.74$ \\
id. peers & 0.15 & - & 0.42 & - & - & - & $\mathrm{F}(1,160)=15.96 ; p \approx 0.000 ; d=0.63$ \\
id. rebels & 0.16 & - & 0.49 & - & - & - & $\mathrm{F}(1,158)=21.62 ; p \approx 0.000 ; d=0.74$ \\
\hline id. peers & - & - & - & 0.41 & 0.21 & - & $\mathrm{F}(1,160)=7.66 ; p=0.006 ; d=0.43$ \\
id. sbd. & - & - & - & 0.43 & 0.25 & - & $\mathrm{F}(1,176)=6.60 ; p=0.011 ; d=0.38$ \\
id. alleg. & - & - & - & 0.47 & 0.32 & - & $\mathrm{F}(1,178)=3.97 ; p=0.048 ; d=0.29$ \\
id. rebels & - & - & - & 0.36 & 0.21 & - & $\mathrm{F}(1,158)=4.46 ; p=0.036 ; d=0.33$ \\
id. alleg. & - & - & - & 0.47 & - & 0.21 & $\mathrm{~F}(1,178)=13.99 ; p \approx 0.000 ; d=0.55$ \\
id. sbd. & - & 0.51 & 0.29 & - & - & - & $\mathrm{F}(1,176)=8.78 ; p=0.003 ; d=0.44$ \\
\hline
\end{tabular}

In what concerns the effects of the level of judgments (positive, neutral, negative) on the mercenaries, we notice (Table 5) that the negative evaluations are higher than the neutral evaluations (with one exception: the utility of allegiants), which in turn are higher than the positive evaluations; and negative evaluations are more numerous than positive ones. 
Table 5. Means and effects of the level of judgment (positive, neutral, negative) on mercenaries.

\begin{tabular}{lcccccccc}
\hline \multirow{2}{*}{$\begin{array}{c}\text { Subjects } \\
\text { Targeted }\end{array}$} & \multicolumn{7}{c}{ Level of Desirability } & \multicolumn{3}{c}{ Level of Utility } & F (Snedecor) and $d$ (Cohen) \\
\cline { 2 - 7 } & Positive & Neutral & Negative & Positive & Neutral & Negative & \\
\hline merc. sbd. & - & 0.34 & 0.61 & - & - & - & $\mathrm{F}(1,176)=13.85 ; p \approx 0.000 ; d=0.56$ \\
merc. peers & - & 0.31 & 0.62 & - & - & - & $\mathrm{F}(1,160)=16.95 ; p \approx 0.000 ; d=0.65$ \\
merc. rebels & - & 0.21 & 0.73 & - & - & - & $\mathrm{F}(1,158)=56.58 ; p \approx 0.000 ; d=1.19$ \\
merc. rebels & - & - & - & - & 0.24 & 0.58 & $\mathrm{~F}(1,158)=21.15 ; p \approx 0.000 ; d=0.73$ \\
merc. peers & - & - & - & - & 0.27 & 0.54 & $\mathrm{~F}(1,160)=13.23 ; p \approx 0.000 ; d=0.57$ \\
merc. alleg. & - & - & - & - & 0.38 & 0.20 & $\mathrm{~F}(1,178)=7.12 ; p=0.008 ; d=0.39$ \\
\hline merc. sbd. & 0.06 & 0.34 & - & - & - & - & $\mathrm{F}(1,176)=25.11 ; p \approx 0.000 ; d=0.75$ \\
merc. peers & 0.07 & 0.31 & - & - & - & - & $\mathrm{F}(1,160)=15.61 ; p \approx 0.000 ; d=0.62$ \\
merc. alleg. & 0.07 & 0.42 & - & - & - & - & $\mathrm{F}(1,178)=36.75 ; p \approx 0.000 ; d=0.90$ \\
merc. rebels & 0.06 & 0.21 & - & - & - & - & $\mathrm{F}(1,158)=7.86 ; p=0.006 ; d=0.44$ \\
merc. sbd. & - & - & - & 0.20 & 0.35 & & $\mathrm{~F}(1,176)=4.84 ; p=0.029 ; d=0.33$ \\
\hline merc. sbd. & 0.06 & - & 0.61 & - & - & - & $\mathrm{F}(1,176)=91.47 ; p \approx 0.000 ; d=1.43$ \\
merc. peers & 0.07 & - & 0.62 & - & - & - & $\mathrm{F}(1,160)=77.44 ; p \approx 0.000 ; d=1.38$ \\
merc. alleg. & 0.07 & - & 0.45 & - & - & - & $\mathrm{F}(1,178)=56.33 ; p \approx 0.000 ; d=1.19$ \\
merc. rebels & 0.06 & - & 0.73 & - & - & - & $\mathrm{F}(1,158)=134.41 ; p \approx 0.000 ; d=1.83$ \\
merc. sbd. & - & - & - & 0.20 & - & 0.45 & $\mathrm{~F}(1,176)=13.15 ; p \approx 0.000 ; d=0.54$ \\
merc. peers & - & - & - & 0.19 & - & 0.54 & $\mathrm{~F}(1,160)=25.70 ; p \approx 0.000 ; d=0.79$ \\
merc. alleg. & - & - & - & 0.20 & - & 0.42 & $\mathrm{~F}(1,178)=10.88 ; p=0.001 ; d=0.49$ \\
merc. rebels & - & - & - & 0.19 & - & 0.58 & $\mathrm{~F}(1,158)=29.90 ; p=0.006 ; d=0.86$ \\
\hline
\end{tabular}

alleg.-allegiant; merc.-mercenary; sbd.--subordinate.

\subsection{Effects of Status}

The evaluations also differ according to the status of the target, but only in what concerns the allegiant target (no difference is observed in terms of the rebel target): if we examine the case of the allegiant taken globally (i.e., by associating the ideological and the mercenary), as in each of its two sides (ideological as well as mercenary), we notice that the subordinates are subjected to less negative judgments than peers (both in terms of desirability, as well as utility) (Table 6).

Table 6. Means and effects of status.

\begin{tabular}{|c|c|c|c|c|c|c|c|}
\hline \multirow{2}{*}{$\begin{array}{l}\text { Subjects } \\
\text { Targeted }\end{array}$} & \multicolumn{2}{|c|}{$\begin{array}{c}\text { Negative } \\
\text { Desirability }\end{array}$} & \multicolumn{2}{|c|}{ Neutral Utility } & \multicolumn{2}{|c|}{ Negative Utility } & \multirow{2}{*}{ F (Snedecor) and $d$ (Cohen) } \\
\hline & sbd. & Peers & sbd. & Peers & sbd. & Peers & \\
\hline alleg. global & 0.56 & 0.98 & - & - & - & - & $\mathrm{F}(1,88)=6.09 ; p=0.016 ; d=0.51$ \\
\hline alleg. id. & 0.10 & 0.40 & - & - & - & - & $\mathrm{F}(1,88)=12.48 ; p=0.001 ; d=0.73$ \\
\hline alleg. global & - & - & - & - & 0.38 & 0.95 & $\mathrm{~F}(1,88)=12.29 ; p=0.001 ; d=0.73$ \\
\hline alleg. id. & - & - & - & - & 0.06 & 0.40 & $\mathrm{~F}(1,88)=18.20 ; p \approx 0.000 ; d=0.87$ \\
\hline alleg. merc. & - & - & - & - & 0.32 & 0.55 & $\mathrm{~F}(1,88)=4.98 ; p=0.028 ; d=0.47$ \\
\hline alleg. global & - & - & 0.84 & 0.53 & - & - & $\mathrm{F}(1,88)=5.288 ; p=0.024 ; d=0.49$ \\
\hline
\end{tabular}

\subsection{Effects of Allegiance/Rebellion}

The evaluations of allegiants and respectively rebels (Table 7), taken globally (without taking into account their ideological and mercenary dimensions), show that the rebels are subjected to more negative evaluations (and less neutral or positive evaluations) than the allegiants. We also notice, if we take into consideration the status of the target, that such differences are only observed when the target is a subordinate. We find similar data for ideological allegiance/rebellion and for mercenary allegiance/rebellion (Table 8). 
Table 7. Means and effects of allegiance/rebellion desirability (globally or considering ideologist and mercenary dimensions).

\begin{tabular}{|c|c|c|c|c|c|c|c|}
\hline \multirow{2}{*}{$\begin{array}{l}\text { Subjects } \\
\text { Targeted }\end{array}$} & \multicolumn{3}{|c|}{ Level of Allegiants Desirability } & \multicolumn{3}{|c|}{ Level of Rebels Desirability } & \multirow{2}{*}{ F (Snedecor) and $d$ (Cohen) } \\
\hline & Positive & Neutral & Negative & Positive & Neutral & Negative & \\
\hline subjects global & - & - & 0.74 & - & - & 1.21 & $\mathrm{~F}(1,168)=12.56 ; p=0.001 ; d=0.56$ \\
\hline sbd. global & - & - & 0.56 & - & - & 1.33 & $\mathrm{~F}(1,87)=24.26 ; p \approx 0.000 ; d=1.04$ \\
\hline id. & - & - & 0.23 & - & - & 0.49 & $\mathrm{~F}(1,168)=11.75 ; p=0.001 ; d=0.55$ \\
\hline id. sbd. & - & - & 0.10 & - & - & 0.54 & $\mathrm{~F}(1,87)=25.82 ; p \approx 0.000 ; d=1.05$ \\
\hline merc. & - & - & 0.51 & - & - & 0.73 & $\mathrm{~F}(1,168)=8.09 ; p=0.005 ; d=0.45$ \\
\hline merc. sbd. & - & - & 0.46 & - & - & 0.79 & $\mathrm{~F}(1,77)=11.38 ; p=0.001 ; d=0.73$ \\
\hline subjects global & - & 1.00 & - & - & 0.56 & - & $\mathrm{F}(1,168)=14.04 ; p \approx 0.000 ; d=0.59$ \\
\hline sbd. global & - & 1.10 & - & - & 0.51 & - & $\mathrm{F}(1,87)=17.18 ; p \approx 0.000 ; d=0.89$ \\
\hline id. & - & 0.58 & - & - & 0.35 & - & $\mathrm{F}(1,168)=8.55 ; p=0.004 ; d=0.47$ \\
\hline id. sbd. & - & 0.64 & - & - & 0.33 & - & $\mathrm{F}(1,87)=8.88 ; p=0.004 ; d=0.64$ \\
\hline merc. & - & 0.42 & - & - & 0.21 & - & $\mathrm{F}(1,168)=8.43 ; p=0.021 ; d=0.46$ \\
\hline merc. sbd. & - & 0.46 & - & - & 0.18 & - & $\mathrm{F}(1,77)=8.26 ; p=0.005 ; d=0.62$ \\
\hline
\end{tabular}

Table 8. Means and effects of allegiance/rebellion utility (globally or considering ideologist and mercenary dimensions).

\begin{tabular}{lccccccc}
\hline \multirow{2}{*}{\begin{tabular}{l} 
Subjects \\
\multicolumn{1}{c}{ Target }
\end{tabular}} & \multicolumn{9}{c}{ Level of Allegiant Utility } & \multicolumn{3}{c}{ Level of Rebels Utility } & \multirow{2}{*}{ F (Snedecor) and $d$ (Cohen) } \\
\cline { 2 - 6 } & Positive & Neutral & Negative & Positive & Neutral & Negative & \\
\hline subjects global & - & - & 0.63 & - & - & 1.00 & $\mathrm{~F}(1,168)=6.69 ; p=0.011 ; d=0.42$ \\
sbd. global & - & - & 0.38 & - & - & 1.10 & $\mathrm{~F}(1,87)=19.37 ; p \approx 0.000 ; d=0.92$ \\
id. & - & - & 0.21 & - & - & 0.43 & $\mathrm{~F}(1,168)=8.52 ; p=0.004 ; d=0.47$ \\
id. sbd. & - & - & 0.06 & - & - & 0.49 & $\mathrm{~F}(1,87)=27.67 ; p \approx 0.000 ; d=1.08$ \\
merc. sbd. & - & - & 0.32 & - & - & 0.62 & $\mathrm{~F}(1,77)=8.27 ; p=0.005 ; d=0.61$ \\
\hline subjects global & - & 0.70 & - & - & 0.45 & - & $\mathrm{F}(1,168)=5.67 ; p=0.018 ; d=0.39$ \\
sbd. global & - & 0.84 & - & - & 0.46 & - & $\mathrm{F}(1,87)=7.11 ; p=0.009 ; d=0.57$ \\
merc. & - & 0.44 & - & - & 0.23 & - & $\mathrm{F}(1,77)=4.34 ; p=0.040 ; d=0.45$ \\
sbd. global & 0.78 & - & - & 0.44 & - & - & $\mathrm{F}(1,87)=4.17 ; p=0.044 ; d=0.44$ \\
id. sbd. & 0.54 & - & - & 0.28 & - & - & $\mathrm{F}(1,87)=6.24 ; p=0.014 ; d=0.54$ \\
\hline
\end{tabular}

id.-ideologist; merc.-mercenary; sbd.—subordinate.

\subsection{Interactions}

It should also be noted that there are six status $\mathrm{x}$ allegiance interactions. They concern negative desirability taken into consideration globally and negative utility taken into consideration globally; negative desirability, positive utility and negative utility attributed to ideological targets; and finally, negative utility attributed to mercenary targets.

\subsubsection{Responses of Overall Negative Desirability and of Overall Negative Utility}

The responses of negative desirability differ significantly $(\mathrm{F}(1,168)=6.631, p=0.011)$ depending on whether we examine global allegiance vs. global rebellion among peers or subordinates. We thus observe that if the target is a subordinate, rebellion leads to a stronger negative desirability than allegiance, whereas this difference fails to occur if the target is a peer. This interaction also means that negative desirability is stronger for peers than for subordinates, but only for allegiance (there is no significant difference in case of rebellion), according to Figure 1a. 


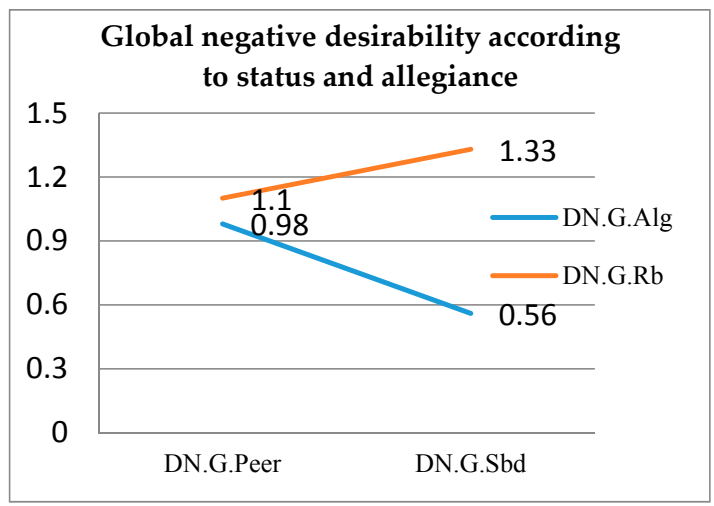

(a)

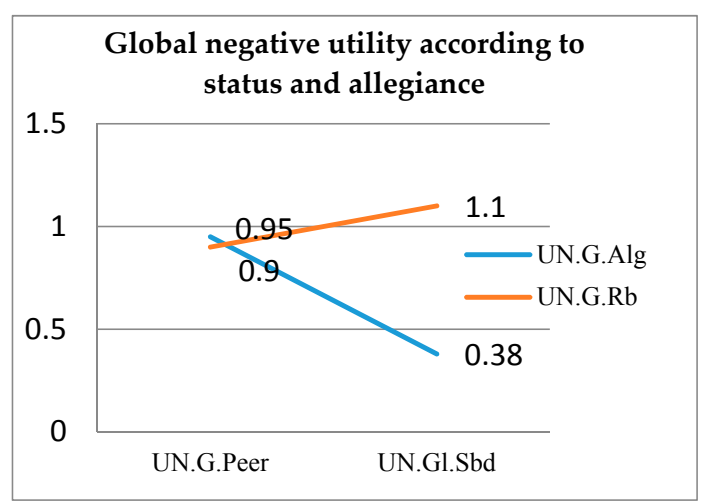

(b)

Figure 1. (a) Responses of global negative desirability (DN) according to status (Peer/Sbd) and the allegiance/rebellion $(\mathrm{Alg} / \mathrm{Rb}$ ) variable; (b) Responses of global negative utility according to status and allegiance/rebellion variable.

The responses of negative utility differ significantly $(\mathrm{F}(1,168)=8.715, p=0.004)$ depending on whether we examine global allegiance vs. global rebellion among peers or among subordinates. We thus observe that if the target is a subordinate, rebellion leads to a stronger negative utility than allegiance, whereas this difference does not appear if the target is a peer. The second significance of this interaction is that negative utility is higher for peers than for subordinates, but solely for allegiance (there is no significant difference for rebellion), according to Figure $1 \mathrm{~b}$.

\subsubsection{Responses of Negative Desirability and of Positive/Negative Utility of Ideologists}

The responses of negative desirability differ significantly $(\mathrm{F}(1,168)=8.224, p=0.005)$ depending on whether we examine ideological allegiance vs. ideological rebellion among peers or among subordinates. Thus, we observe a more intense negative desirability towards rebels as compared to allegiants, but solely if the target is a subordinate, and moreover the difference in terms of peer/subordinate negative desirability is significant among ideological allegiants but not among ideological rebels (according to Figure 2a).

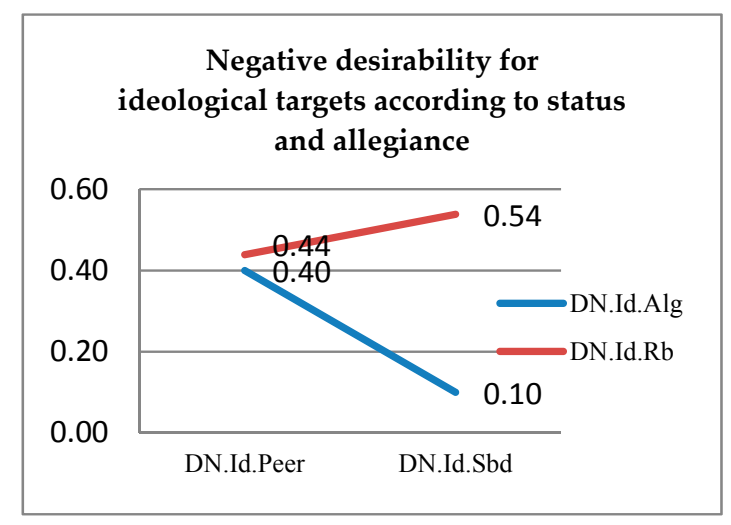

(a)

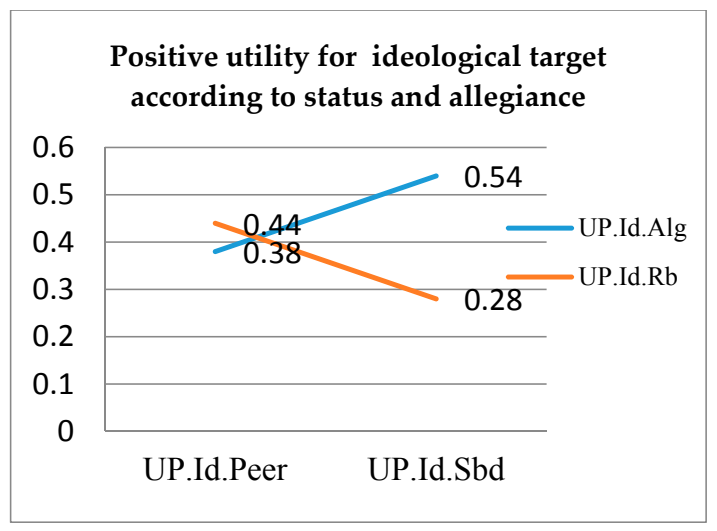

(b)

Figure 2. (a) Responses of negative desirability (DN) for ideological (Id) targets according to status (Peer/Sbd) and the allegiance(Alg)/rebellion(Rb) variable; (b) Responses of positive utility (UP) for ideological(Id) targets according to status (Peer/Sbd) and the allegiance(Alg)/rebellion(Rb) variable.

The responses of positive utility differ significantly $(\mathrm{F}(1,168)=4.551, p=0.034)$ depending on whether we examine ideological allegiance vs. ideological rebellion among peers or among 
subordinates. Thus we observe that if the target is a subordinate, ideological allegiance leads to a higher positive utility than the ideological rebellion, whereas there is no difference if the target is a peer (according to Figure $2 b$ ).

The responses of negative utility differ significantly $(\mathrm{F}(1,168)=11.736, p=0.001)$ depending on whether we examine ideological allegiance vs. ideological rebellion among peers or among subordinates. Thus we observe that if the target is a subordinate, ideological rebellion leads to a stronger negative utility than ideological allegiance, whereas this difference fails to occur if the target is a peer. The second signification of this interaction is that negative utility is stronger for peers than for subordinates, but only in terms of ideological allegiance (there is no significant difference in the case of ideological rebellion) (according to Figure 3).

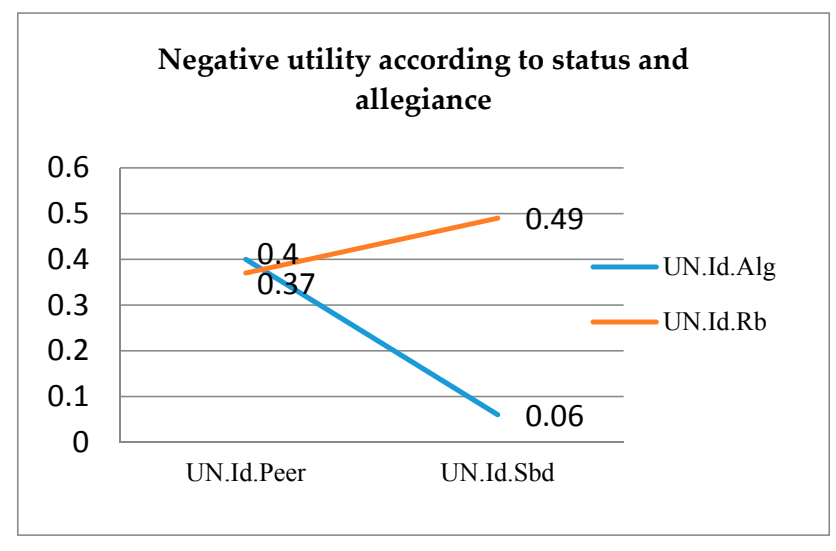

Figure 3. Responses of negative utility (UN) for ideological targets (Id) according to status (Peer/Sbd) and the allegiance $(\mathrm{Alg}) /$ rebellion $(\mathrm{Rb})$ variable.

\subsubsection{Responses of Negative Utility in Case of Mercenaries}

Negative utility responses differ significantly $(\mathrm{F}(1,168)=4.143, p=0.043)$ depending on whether we examine mercenary allegiance vs. mercenary rebellion among peers or among subordinates. Thus, we observe that if the target is a subordinate, mercenary rebellion leads to a stronger negative utility than mercenary allegiance, whereas this difference does not occur if the target is a peer. This interaction also signifies that negative utility is stronger for peers than for subordinates, but solely in terms of mercenary allegiance (there is no significant difference in terms of mercenary rebellion) (according to Figure 4).

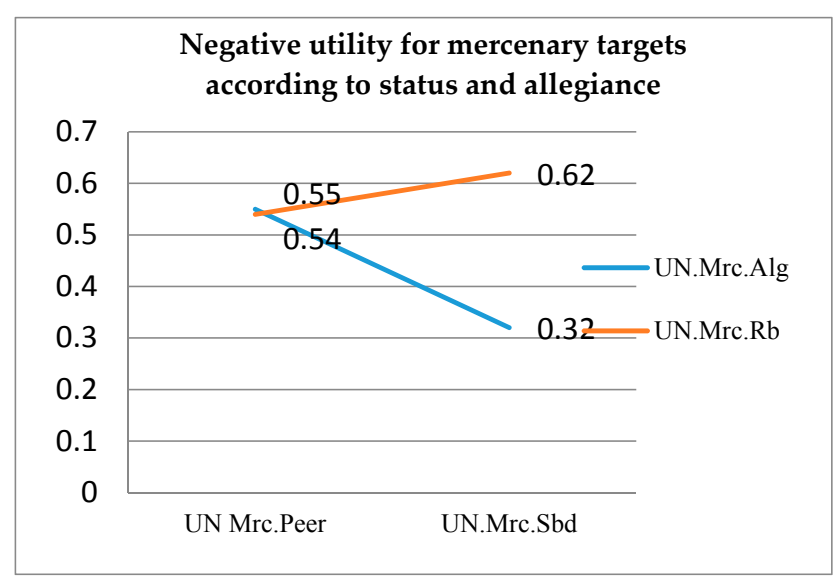

Figure 4. Responses of negative utility for mercenary targets according to status (Peer/Sbd) and the allegiance $(\mathrm{Alg}) /$ rebellion $(\mathrm{Rb})$ variable. 


\section{Discussion}

In this article, we have been interested in the social value attributed to allegiant or non-allegiant employees and whether this value is different when we speak of social desirability or social utility, when we speak of positive, neutral or negative judgments, or when we speak of a peer or subordinate allegiant (non-allegiant).

We first notice that each of our four variables has an effect, whether it is about the type or the level of judgment, status, or even allegiance/rebellion.

Several studies have shown that utility and desirability are two distinct dimensions. Thus, Cambon, Djouary, and Beauvois; Dubois; or Testé, Joufre, and Somat [29,33,37] noted that internality (i.e., the tendency to declare oneself responsible for our actions or what happens to us) [38,39] was more rooted in utility than in desirability. Cambon, Djouary, and Beauvois [33] and Dubois [29] observed that this was also the case for self-sufficiency (finding in oneself the answers to the questions we ask ourselves [40]). Conversely, Dubois found that the individual anchor norm (i.e., the tendency to see our psychological reality without reference to our categorical or group membership) is more rooted in desirability [29]. About allegiance, Gangloff [36] has also previously observed (but in a study on the value of information about the allegiance and not, as is the case here, on the value assigned to the allegiance itself: cf. above) that utility and desirability were separate. It is hereby confirmed, according to our hypothesis, that the utility and desirability of allegiance (considered in itself) do not lead to identical judgements, and more particularly that positive judgments are higher for utility than for desirability. In their positive judgments, the evaluators thus attribute more importance to utility than to desirability. It is therefore interesting to observe, in terms of mercenary targets, that it is the judgment of desirability that leads to more intense negative evaluations: mercenaries are therefore further rejected based on emotional reasons than due to a questioning of their utility.

We also notice, in what concerns the level of judgment (positive, neutral, or negative) examined globally or regarding mercenary targets, that the negative evaluations are generally higher than neutral evaluations, which in turn are higher than the positive evaluations. On the contrary, in what concerns the effects of the level of judgment on the ideological targets, the results are more heterogeneous, with practically as many cases in the global sense as in the reverse sense. The fact that this heterogeneity only concerns the ideological targets tends to show a preference for ideologists as compared to mercenaries: an individual that acts opportunistically, such as the mercenary, will be rejected more than the individual responding to an ideology, principles, and regardless of the direction of their behavior (allegiant or rebel). This result joins that obtained by Duchon and Gangloff in 2008 [20].

The evaluations also differ according to the status of the target, but only in what concerns the allegiant target (no difference was observed in terms of the rebel target): whether they are ideologists or mercenaries, peers are subject to more intense negative judgments than the subordinates, both in terms of desirability and utility. Consistent with our hypothesis, they are more severe towards the endo-group than the exo-group.

In what regards the allegiance/rebellion variable, it is observed (both globally, as well as according to their sub-dimension: ideological/mercenary) that even if the allegiant is not subjected to more positive evaluations than the rebel (except for utility), on the contrary, the rebel is always subjected to more important negative evaluations than the allegiant. The fact that the differences of judgments between allegiant targets and rebel targets come mostly from more negative judgments passed on rebels than more positive judgments passed on allegiants opens the way for an inquiry on the bipolarity of the level of judgment, meaning to a reflection on the possible absence of a corollary between valuation and devaluation. Moreover, it is also worth noting, if we take into consideration the status of the target, that such differences are only observed when the target is a subordinate. Therefore, we once more encounter more lenience towards the exo-group.

Finally, the status $x$ allegiance interaction highlights that the responses on utility or desirability differ according to whether we are examining allegiance vs. rebellion among peers or among subordinates. Therefore, an allegiant subordinate obtains less negative responses, both in terms 
of utility and desirability, as compared to an allegiant peer or a rebel subordinate. We also observe, in the case of ideological allegiance and rebellion, a stronger intensity of negative desirability and utility towards rebels as compared to allegiants, and, in reverse, a stronger intensity of positive utility for allegiants than for rebels, but in all three cases only if the target is a subordinate. Finally, if we examine the case of mercenaries, we notice that mercenary rebellion leads to a stronger negative utility than mercenary allegiance, but again only if the target is a subordinate.

However, we should indicate a certain number of limitations to these results. The first is the absence of any contextualization with regards to the function of the future collaborator. Evidently, expectations may differ according to the type of function exerted by the future collaborator, be it a future peer or a future subordinate. It would therefore be appropriate, in a subsequent study, to refine this aspect and to vary the function in order to operationalize it as an independent variable. But contextualization does not only concern the function of the future collaborator: it may reveal gender, age, etc. Also, since our participants were only male (our results are not necessarily transferable to a female population), it would be interesting to examine the potential effect of the gender of the target, with a factorial plan in which the participants are divided into two groups (one group of males and one group of females): it is not certain that we will obtain similar results for each of the four groups. As it can be observed, the present results open the way to numerous new questions, and therefore to numerous additional studies. However, they already have a number of practical applications. Thus, in terms of recruitment, the focus is often exclusively, at least explicitly, on the technical skills of the candidates, forgetting the relational aspect, the atmosphere at work. The present results could enable recruitment officers as well as job applicants to become more aware of the importance of the relational aspect. Such awareness could enable recruitment officers to operationalize this relational aspect more explicitly, including taking into account the allegiance criterion; consequently, such awareness and such explicitation could also enable job applicants to better prepare for their selection interviews.

\section{Conclusions}

We are interested in presenting an interpretation of our results about allegiant behavior from the perspective of sustainable development. Most often, undertaking a behavior that would support sustainable development involves effort, discomfort, or additional financial costs. Many sustainable behaviors have positive collective consequences, but negative individual ones. Therefore, the person who assumes a sustainable behavior must be motivated and act according to values that support the sustainable development of society.

The decision to assume a sustainable behavior reflects a person's attachment to certain principles, values, and beliefs. By definition, allegiant people are characterized by adhering to and supporting the values of the organization they belong to, contributing through their acts to the maintenance, preservation, and sustainability of social order and the existing organizational structure.

A first result of our work highlights the valuation of allegiant behavior within a company, which means that an allegiant employee is appreciated and valued more than a rebellious employee whose negative assessments are always more numerous than those for the allegiant. Allegiant people are not appreciated because they are more agreeable, although their social desirability is somewhat valued as well. The results show that allegiant persons are appreciated more in terms of their social utility. Being able to integrate within the organizational world without disturbing it, rapidly identifying with the organization, easily complying with the rules and norms of the organization, and especially because they conform to any authority without jeopardizing the hierarchy of power, allegiant people are considered useful for the organization and the social environment they belong to.

By analyzing the results, we identify a preference for the allegiant ideologist, who acts by virtue of certain principles and ideologies, as compared with the allegiant mercenary who has opportunistic purposes and, through his/her obedience, only aims to achieve their personal goals. 
In what regards the status of the persons assessed, be they subordinates or peers, we obtained a greater valorization of allegiant persons if they are subordinates and a lower valorization if they are peers, meaning that a leader appreciates more allegiant subordinates than allegiant peers.

Promoting a transition to a sustainable society must be done with motivated people who would invest time and assume certain additional costs. Within an organization, the issue of sustainability must be approached on the one hand from the perspective of leaders who assume a sustainable leadership, and there are plenty of studies there of that aim to identify the skills necessary for a leader to successfully implement the transition to a sustainable organization [7,41-44].

However, the issue of sustainability must also be approached from the perspective of the employees, who can adhere to the leader's values, thus facilitating the implementation of sustainability, or who can rebel against the leader when the requests of the latter may bring personal prejudices (for example, additional costs) or generate a certain discomfort, and then the rebel person is not willing to accept the leader's demands and will hinder the implementation of the measures established by the leader.

The results of our work on allegiant behavior may have practical implications within the field of implementing sustainability within an organization. When selecting the team with whom one wants to make the transition to a sustainable organization, one must take into account their availability to preserve the social order and encourage ideological reproduction.

An organization undergoing transition towards a durable development, with a sustainable leadership, also requires employees who believe in the leader's values, who believe in the values of sustainability and who would comply with the rules and norms that support sustainable development. Allegiant people acting based on an ideology that values sustainability are loyal, comply with rules, and follow the existing norms imposed by a sustainable leadership, not because they are afraid of repression, but because they are committed and act in accordance with their beliefs on the necessity of implementing sustainable development and because they will not disturb the organizational structure.

Our results highlight a valuation of allegiant behavior within an organization, especially when it comes to a collaboration between the leader and his subordinates that gives confidence in the chances of implementing a transition to a sustainable organization.

Acknowledgments: There are no sources of funding for the study or grants received for the research. There are no resources for publication in free access.

Author Contributions: Crisanta-Alina Mazilescu conceived the experiments and analyzed the data; Bernard Gangloff conceived, designed and performed the experiments; Crisanta-Alina Mazilescu and Bernard Gangloff wrote the paper.

Conflicts of Interest: The authors declare no conflict of interest.

\section{Appendix A. Items of the Questionnaire}

Items of ideological allegiance: Imagine that you will soon have a new work colleague (vs. a new subordinate), and that the only information you have on that person is that they said:

(1) When my boss makes a decision, I never question it, regardless of his/her decision: one should not argue with one's boss!

(2) never try to defend my ideas when I see that they differ from that of my boss: the boss is the boss!

(3) I always follow the orders I get from my boss, even when those orders may seem idiotic: a follower has to follow and that's it!

Items of ideological rebellion: Imagine that you will soon have a new work colleague (vs. a new subordinate), and that the only information you have on that person is that they said:

(1) When I don't agree with my boss, I always tell him/her: the law also grants rights to employees, which should be exerted or otherwise they will be lost! 
(2) When my boss makes bad decisions, I never hesitate to question them: I have principles and I don't see why I should keep silent.

(3) If I disagree with my boss' orders, I will not obey them: only because he/she is the boss does not mean we have to obey him/her like slaves!

Items of mercenary allegiance: Imagine that you will soon have a new work colleague (vs. a new subordinate), and that the only information you have on that person is that they said:

(1) Even if the orders given by my boss sometimes seem absurd, because I want to be rapidly promoted, I always obey them!

(2) I always avoid defending my point of view when it contradicts my boss' point of view: it's better to act like this if I want to get a higher wage.

(3) Because I want to be well-thought of by my boss, I always respect his/her decisions, regardless of what they are!

Items of mercenary rebellion: Imagine that you will soon have a new work colleague (vs. a new subordinate), and that the only information you have on that person is that they said:

(1) When my boss gives me orders which seem to be inadequate, if those orders interfere with me achieving my goals or receiving my bonuses, I never follow them!

(2) When I see that my direct superior has bad ideas, I always inform the "big bosses": one day, I will be rewarded for it!

(3) When I see that the decisions of my boss may prevent me from getting a promotion, I never hesitate to protest!

\section{Appendix B. Gross Results}

Table A1. Distribution of responses provided for allegiance/rebellion taken globally (occurrences and means ${ }^{*}$ ).

\begin{tabular}{|c|c|c|c|c|c|c|c|c|c|}
\hline \multirow{2}{*}{\multicolumn{2}{|c|}{ Subjects Targeted }} & \multicolumn{4}{|c|}{ Desirability } & \multicolumn{4}{|c|}{ Utility } \\
\hline & & \multirow{2}{*}{$\begin{array}{c}\text { Positive } \\
6(0,08)\end{array}$} & \multirow{2}{*}{$\begin{array}{l}\text { Neutral } \\
35(0.43)\end{array}$} & \multirow{2}{*}{$\frac{\text { Negative }}{39(0.49)}$} & \multirow{2}{*}{$\begin{array}{c}\text { Total } \\
80(1)\end{array}$} & \multirow{2}{*}{$\begin{array}{l}\text { Positive } \\
21(0.26)\end{array}$} & \multirow{2}{*}{$\begin{array}{l}\text { Neutral } \\
21(0.26)\end{array}$} & \multirow{2}{*}{$\frac{\text { Negative }}{38(0.48)}$} & \multirow{2}{*}{$\begin{array}{r}\text { Total } \\
80(1)\end{array}$} \\
\hline & peer & & & & & & & & \\
\hline & sbd. & 17 (0.17) & $54(0.54)$ & $29(0.29)$ & $100(1)$ & 39 (0.39) & $42(0.42)$ & 19 (0.19) & $100(1)$ \\
\hline & tot & $23(0.13)$ & $89(0.49)$ & $68(0.38)$ & $180(1)$ & $60(0.33)$ & $63(0.35)$ & $57(0.32)$ & $180(1)$ \\
\hline \multirow{3}{*}{$\begin{array}{l}\text { rebel id. } \\
\text { + merc. }\end{array}$} & peer & $12(0.15)$ & $25(0.30)$ & $45(0.55)$ & $82(1)$ & $27(0.33)$ & $18(0.22)$ & $37(0.45)$ & $82(1)$ \\
\hline & sbd & $6(0.07)$ & $20(0.26)$ & $52(0.67)$ & 78 (1) & $17(0.22)$ & $18(0.23)$ & $43(0.55)$ & $78(1)$ \\
\hline & tot & $18(0.11)$ & $45(0.28)$ & $97(0,61)$ & $160(1)$ & $44(0.28)$ & $36(0.22)$ & $80(0.50)$ & $160(1)$ \\
\hline \multirow{3}{*}{ Total } & peer & $18(0.11)$ & $60(0.37)$ & $84(0,52)$ & $162(1)$ & $48(0.30)$ & $39(0.24)$ & $75(0.46)$ & $162(1)$ \\
\hline & sbd & $23(0.13)$ & $74(0.42)$ & $81(0.45)$ & 178 (1) & $56(0.31)$ & $60(0.34)$ & $62(0.35)$ & $178(1)$ \\
\hline & tot & $41(0.12)$ & $134(0.39)$ & $165(0,49)$ & $340(1)$ & $104(0.31)$ & $99(0.29)$ & $137(0.40)$ & 340 (1) \\
\hline
\end{tabular}

alleg.-allegeant; id.-ideologist; merc.-mercenary; sbd.—subordinate; tot.-total; *—means are indicated between parantheses. 
Table A2. Distribution of responses provided for allegiance/rebellion legalists (occurrences and means *).

\begin{tabular}{cccccccccc}
\hline \multirow{2}{*}{ Subjects Targeted } & \multicolumn{5}{c}{ Desirability } & \multicolumn{4}{c}{ Utility } \\
\cline { 3 - 9 } & & Positive & Neutral & Negative & Total & Positive & Neutral & Negative & Total \\
\hline \multirow{3}{*}{ alleg. id. } & peer & $4(0.10)$ & $20(0.50)$ & $16(0.40)$ & $40(1)$ & $15(0.375)$ & $9(0.225)$ & $16(0.40)$ & $40(1)$ \\
& sbd. & $13(0.26)$ & $32(0.64)$ & $5(0.10)$ & $50(1)$ & $27(0.54)$ & $20(0.40)$ & $3(0.06)$ & $50(1)$ \\
& total & $17(0.19)$ & $51(0.57)$ & $22(0.24)$ & $90(1)$ & $42(0.47)$ & $29(0.47)$ & $19(0.21)$ & $90(1)$ \\
\hline \multirow{3}{*}{ rebel id. } & peer & $8(0.195)$ & $15(0.365)$ & $18(0.44)$ & $41(1)$ & $18(0.44)$ & $8(0.195)$ & $15(0.365)$ & $41(1)$ \\
& sbd. & $5(0.13)$ & $13(0.33)$ & $21(0.54)$ & $39(1)$ & $11(0.28)$ & $9(0.195)$ & $19(0.49)$ & $39(1)$ \\
& total & $13(0.16)$ & $28(0.35)$ & $39(0.49)$ & $80(1)$ & $29(0.36)$ & $17(0.23)$ & $34(0.43)$ & $80(1)$ \\
\hline \multirow{3}{*}{ total } & peer & $12(0.15)$ & $35(0.43)$ & $34(0.42)$ & $81(1)$ & $33(0.41)$ & $17(0.21)$ & $31(0.38)$ & $81(1)$ \\
& sbd. & $18(0.20)$ & $44(0.50)$ & $27(0.30)$ & $89(1)$ & $38(0.43)$ & $29(0.32)$ & $22(0.25)$ & $89(1)$ \\
& total & $30(0.18)$ & $79(0.46)$ & $61(0.36)$ & $170(1)$ & $71(0.42)$ & $46(0.27)$ & $53(0.31)$ & $170(1)$ \\
\hline
\end{tabular}

alleg.--allegeant; id.—ideologist; sbd.—subordinate; tot.—total; ${ }^{*}$-means are indicated between parantheses.

Table A3. Distribution of responses provided for allegiance/rebellion opportunists (occurrences and means *).

\begin{tabular}{cccccccccc}
\hline \multicolumn{2}{c}{ Subjects Targeted } & \multicolumn{5}{c}{ Desirability } & \multicolumn{4}{c}{ Utility } \\
\cline { 3 - 9 } & & Positive & Neutral & Negative & Total & Positive & Neutral & Negative & Total \\
\hline \multirow{2}{*}{ alleg. } & Peer & $2(0.05)$ & $15(0.375)$ & $23(0.575)$ & $40(1)$ & $6(0.15)$ & $12(0.30)$ & $22(0.55)$ & $40(1)$ \\
merc. & Sbd & $4(0.08)$ & $23(0.46)$ & $23(0.46)$ & $50(1)$ & $12(0.24)$ & $22(0.44)$ & $16(0.32)$ & $50(1)$ \\
& Tot & $6(0.07)$ & $38(0.42)$ & $46(0.51)$ & $90(1)$ & $18(0.20)$ & $34(0.38)$ & $38(0.42)$ & $90(1)$ \\
\hline \multirow{2}{*}{ reb. } & Peer & $4(0.10)$ & $10(0.24)$ & $27(0.66)$ & $41(1)$ & $9(0.22)$ & $10(0.24)$ & $22(0.54)$ & $41(1)$ \\
merc. & Sbd & $1(0.03)$ & $7(0.18)$ & $31(0.79)$ & $39(1)$ & $6(0.15)$ & $9(0.23)$ & $24(0.62)$ & $39(1)$ \\
& Tot & $5(0.06)$ & $17(0.21)$ & $58(0.73)$ & $80(1)$ & $15(0.19)$ & $19(0.23)$ & $46(0.58)$ & $80(1)$ \\
\hline \multirow{3}{*}{ total } & Peer & $6(0.07)$ & $25(0.31)$ & $50(0.62)$ & $81(1)$ & $15(0.19)$ & $22(0.27)$ & $44(0.54)$ & $81(1)$ \\
& Sbd & $5(0.06)$ & $30(0.34)$ & $54(0.60)$ & $89(1)$ & $18(0.20)$ & $31(0.35)$ & $40(0.45)$ & $89(1)$ \\
& Tot & $11(0.06)$ & $55(0.33)$ & $104(0.61)$ & $170(1)$ & $33(0.19)$ & $53(0.31)$ & $84(0.50)$ & $170(1)$ \\
\hline
\end{tabular}

alleg.—allegeant; reb.-rebel; merc.-mercenary; sbd.—subordinate; tot-total; * —means are indicated between parantheses.

\section{References}

1. Omann, I.; Spangenberg, J.H. Assessing Social Sustainability. The Social Dimension of Sustainability in a Socio-Economic Scenario. In Proceedings of the 7th Biennial Conference of the International Society for Ecological Economics, Sousse, Tunisia, 6-9 March 2002.

2. Wolbring, G.; Rybchinski, T. Social Sustainability and its Indicators through a disability studies lens. Sustainability 2013, 5, 4889-4907. [CrossRef]

3. Widok, A.H.; Wohlgemuth, V. Definition of Social Sustainability Criteria for the Simulation of OHS in Manufacturing Entities. In Proceedings of the 29th EnviroInfo and 3rd ICT4S Conference, Copenhagen, Denmark, 7-9 September 2015.

4. Cao, Y.; Wang, S.; Yi, L.; Zhou, J. A Social Sustainability Assessment Model for Manufacturing Systems Based on Ergonomics and Fuzzy Inference System. In Sustainable Design and Manufacturing 2016; Setchi, R., Howlett, R.J., Liu, Y., Theobald, P., Eds.; Springer: Berlin/Heidelberg, Germany, 2016; pp. 639-648.

5. Jasiulewicz-Kaczmarek, M.; Saniuk, A. Human factor in Sustainable Manufacturing. In Universal Access in Human-Computer Interaction. Access to the Human Environment and Culture; Antona, M., Stephanidis, C., Eds.; Springer: Berlin/Heidelberg, Germany, 2015; pp. 444-455.

6. Chiu, R. Social sustainability and sustainable housing. In Housing and Social Change: East, West Perspectives; Forrest, R., Lee, J., Eds.; Routledge: London, UK, 2003; pp. 221-239.

7. Dent, P.; Patrick, M.; Ye, X. Property Markets and Sustainable Behaviour; Routledge: New York, NY, USA, 2012.

8. Buil, M.; Aznar, J.P.; Galiana, J.; Rocafort-Marco, A. An Explanatory Study of MBA Students with Regards to Sustainability and Ethics Commitment. Sustainability 2016, 8, 280. [CrossRef] 
9. Gardiner, S.; Rieckmann, M. Pedagogies of Preparedness: Use of Reflective Journals in the Operationalisation and Development of Anticipatory Competence. Sustainability 2015, 7, 10554-10575. [CrossRef]

10. Cebrián, G.; Junyent, M. Competencies in Education for Sustainable Development: Exploring the Student Teachers' Views. Sustainability 2015, 7, 2768-2786. [CrossRef]

11. Sammalisto, K.; Sundström, A.; von Haartman, R.; Holm, T.; Yao, Z. Learning about Sustainability-What Influences Students' Self-Perceived Sustainability Actions after Undergraduate Education? Sustainability 2016, 8, 510. [CrossRef]

12. Steg, L.; Perlaviciute, G.; van der Werff, E. Understanding the human dimensions of a sustainable energy transition. Front. Psychol. 2015, 6, 805. [CrossRef] [PubMed]

13. Steg, L.; Bolderdijk, J.W.; Keizer, K.; Perlaviciute, G. An integrated framework for encouraging pro-environmental behaviour: the role of values, situational factors and goals. J. Environ. Psychol. 2014, 38, 104-115. [CrossRef]

14. Steg, L.; Perlaviciute, G.; van der Werff, E.; Lurvink, J. The significance of hedonic values for environmentally-relevant attitudes, preferences and actions. Environ. Behav. 2014, 46, 163-192. [CrossRef]

15. Abrahamse, W.; Steg, L. Social influence approaches to encourage resource conservation: A meta-analysis. Glob. Environ. Chang. 2013, 23, 1773-1785. [CrossRef]

16. Gangloff, B. La norme d'allégeance. In Psychologie et Recrutement; Laberon, S., Ed.; De Boeck: Bruxelles, Belgium, 2011; pp. 177-197.

17. Bucchioni, S. Rôles Respectifs de L'internalité et de L'allégeance dans L'évaluation Professionnelle; Mémoire non publié; Université de Reims Champagne-Ardenne: Reims, France, 2001.

18. Dagot, L. L'allégeance et l'internalité dans le travail d'aide à l'insertion professionnelle: Le cas du bilan de compétences. In Proceedings of the Communication au 11ème Congrès International de Psychologie du Travail de Langue Française, Rouen, France, 23-25 August 2000.

19. Dagot, L. Normativité de L'allégeance et de L'internalité: Le Cas Des Acteurs du Marché du Travail. Ph.D. Thesis, Université de Bordeaux 2, Bordeaux, France, 2002.

20. Legrain, H.; Dagot, L. Internalité et allégeance. Actes du Colloque AFPA/INOIP/AIPLF. In L'Approche Psychologique du Travail; AFPA/AIPTLF: Lille, France, 2005; pp. 65-70.

21. Dagot, L.; Castra, D. L'allégeance: Un principe des logiques d'aide à l'insertion professionnelle. L'orientat. Sc. Prof. 2002, 31, 417-442. [CrossRef]

22. Dagot, L. Conseiller et recruter: des logiques sociales d'évaluation. Cah. Int. Psychol. Soc. 2004, 63, 93-106.

23. Duchon, C.; Gangloff, B. Differential valorization of the unemployed persons according to the ideological or mercenary reason of their support versus non support for the allegiance norm. In Proceedings of the Actes de la 5th International Conference of Applied Psychology, Timisoara, Roumanie, 2007; Editura Eurobit: Timisoara, Roumanie, 2008; pp. 177-182.

24. Gilles, I.; Scheidegger, R.; Toma, C. Who likes the rebels and who likes the allegiants? The role of membership and status in the judgment of rebel attributions. Rev. Int. Psychol. Soc. 2011, 24, 83-106.

25. Gangloff, B.; Mayoral, L. Influencia del nivel de alineacion y del genero sobre las decisiones de administracion y de reclutamiento de personal en las empresas argentinas. Bol. Psicol. 2008, 94, 23-45.

26. Gangloff, B.; Mayoral, L. La percepcion de los obreros, ejecutivos del nivel medio y sindicalistas argentinos respecto del nivel de alineacion conveniente para ser reclutados. Interam. J. Psychol. 2008, 42, 338-352.

27. Beauvois, J.-L.; Dubois, N.; Peeters, G. L'évaluation personnologique. In La Construction Sociale de la Personne; Beauvois, J.-L., Dubois, N., Doise, W., Eds.; PUG: Grenoble, France, 1999; pp. 259-279.

28. Cambon, L. Désirabilité et utilité sociale, deux composantes de la valeur. Une exemplification dans l'analyse des activités professionnelles. L'Orientat. Sc. Prof. 2002, 31, 75-96. [CrossRef]

29. Dubois, N. Normes sociales de jugement et valeur: Ancrage sur l'utilité et ancrage sur la désirabilité. Rev. Int. Psychol. Soc. 2005, 18, 43-79.

30. Dubois, N.; Beauvois, J.-L. Evaluation et connaissance évaluative: Une théorie dualiste de la connaissance. Nouv. Rev. Psychol. Soc. 2001, 1, 101-111.

31. Peeters, G. Good and evil as softwares of the brain: On psychological immediates underlying the metaphysical ultimates. Interdiscip. Stud. Philos. Underst. 1986, 9, 210-231.

32. Beauvois, J.-L. La connaissance des utilités sociales. Psychol. Fr. 1995, 40, 375-388.

33. Cambon, L.; Djouary, N.; Beauvois, J.-L. Social norms of judgment and social utility: When it is more profitable to be useful than desirable. Swiss J. Psychol. 2006, 65, 167-180. [CrossRef] 
34. Le Barbenchon, E.; Cambon, L.; Lavigne, F. Désirabilité et utilité sociale de 308 adjectifs de personnalité et 297 professions. L'année Psychol. 2005, 105, 307-322. [CrossRef]

35. Mazilescu, C.A.; Abdellaoui, S.; Gangloff, B. Assessing the social value of personality information. Rev. Cercet. Interv. Soc. 2012, 38, 91-106.

36. Gangloff, B. Utilité et Désirabilité D'informations Normatives sur Des Subordonnés et Des Collègues de Travail. Les Cahiers de Psychologie Politique. 2010. Available online: http://lodel.irevues.inist.fr/ cahierspsychologiepolitique/index.php?id=1678 (accessed on 24 May 2016).

37. Testé, B.; Joufre, S.; Somat, A. L'expression de la préférence pour la consistance est-elle une norme de jugement comparable à l'expression de l'internalité? L'Année Psychol. 2010, 110, 379-399. [CrossRef]

38. Lefcourt, H.M. Internal vs external control of reinforcement: A review. Psychol. Bull. 1966, 65, $206-220$. [CrossRef] [PubMed]

39. Rotter, J.B. Generalized expectancies for internal versus external control of reinforcement. Psychol. Monogr. 1966, 80, 1-28. [CrossRef] [PubMed]

40. Sampson, E.E. Psychology and the American ideal. J. Personal. Soc. Psychol. 1977, 35, 767-782. [CrossRef]

41. Scott, W.; Gough, S. Sustainable Development and Learning. Framing the Issue; Routledge Falmer: London, UK, 2003.

42. Scott, W.; Gough, S. Key Issues in Sustainable Development and Learning, a Critical Review; Routledge Falmer: London, UK, 2003.

43. Fawcett, L.; Bell, A.C. Guiding our environmental praxis: Teaching and learning for social and environmental justice. In Teaching Sustainability at Universities: Towards Curriculum Greening; Leal Filho, W., Ed.; Peter Lang: New York, NY, USA, 2002.

44. Sterling, S. Sustainable Education; Green Books: Totnes, UK, 2001.

(C) 2017 by the authors; licensee MDPI, Basel, Switzerland. This article is an open access article distributed under the terms and conditions of the Creative Commons Attribution (CC BY) license (http:/ / creativecommons.org/licenses/by/4.0/). 